\title{
A MATTER OF EXPERIENCE AND PERCEPTION: EXAMINING CORRUPTION IN LATIN AMERICA
}

by

Nicolás Adrián Diaz

\author{
A thesis \\ submitted in partial fulfillment \\ of the requirements for the degree of \\ Master of Arts in Political Science \\ Boise State University
}

May 2018 
(C) 2018

Nicolás Adrián Diaz

ALL RIGHTS RESERVED 


\title{
BOISE STATE UNIVERSITY GRADUATE COLLEGE
}

\section{DEFENSE COMMITTEE AND FINAL READING APPROVALS}

\author{
of the thesis submitted by
}

\author{
Nicolás Adrián Diaz
}

Thesis Title: A Matter of Experience and Perception: Examining Corruption in Latin America

Date of Final Oral Examination: $\quad 28$ February 2018

The following individuals read and discussed the thesis submitted by student Nicolás Adrián Diaz, and they evaluated his presentation and response to questions during the final oral examination. They found that the student passed the final oral examination.

Nisha Bellinger, Ph.D.

Julie VanDusky-Allen, Ph.D.

Stephen M. Utych, Ph.D.
Chair, Supervisory Committee

Member, Supervisory Committee

Member, Supervisory Committee

The final reading approval of the thesis was granted by Nisha Bellinger, Ph.D., Chair of the Supervisory Committee. The thesis was approved by the Graduate College. 


\section{DEDICATION}

I would like to dedicate the completed work to my parents, Nora, Daniel, and Mike. Their support and encouragement carried me through the process. Your love helped me attain it. Additionally, a special thanks to all my friends that listened to my rants, theories, and complaints and knew exactly what to say to inspire me. Mel, Lynne, Yazmin, and countless others that cheered me through this process, I cannot thank you enough.

Mabi, Ana, Quique, Luis, siempre en mí corazón y un agradecimiento de por vida. 


\section{ACKNOWLEDGEMENTS}

I would like to thank and compliment my thesis committee, Nisha Bellinger, Julie VanDusky-Allen, and Steve Utych, as well as Michael Allen for their immense support, patience, and helpful advice they provided through this process. Their contribution cannot be measured, but it can be praised. Twyla and Valerie, your guidance cannot go unnoticed. Thank you. 


\begin{abstract}
The pervasive nature of corruption poses many challenges to nations. In particular, it can hamper progress and threaten stability. However, a citizen's awareness of corruption is not exclusively based on encountering it personally. I claim that experience and perception of corruption are two distinct features, influencing an individual's satisfaction with democracy. This study utilizes a mediation analysis to determine the impact of corruption, both experienced and perceived, on an individual's satisfaction with democracy in Latin America. The statistical technique distinguishes the influence of experiencing corruption first-hand and having a high perception of it when determining a citizen's support for democratic values, taking into consideration joint and distinct effects. I use the Latin American Public Opinion Project (LAPOP) biannual survey from 2006-2014, using responses from 22 countries. This study underscores the ramifications of corruption as it determines perception is only partially influenced by experience and impacts citizens' views on democracy negatively.
\end{abstract}


TABLE OF CONTENTS

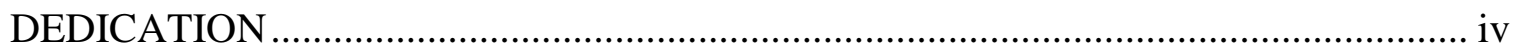

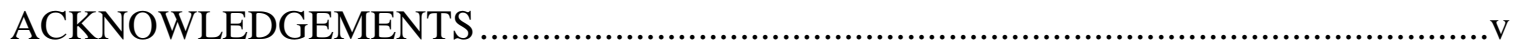

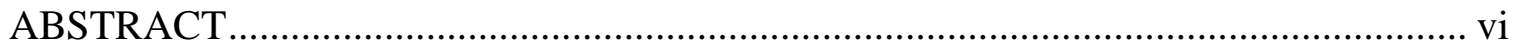

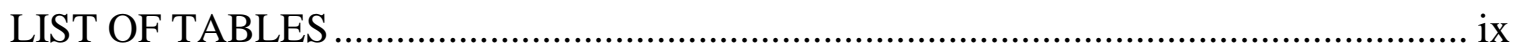

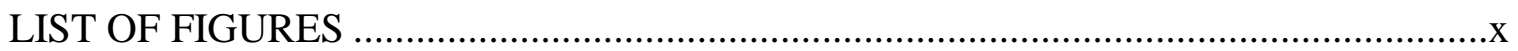

LIST OF ABBREVIATIONS ............................................................................

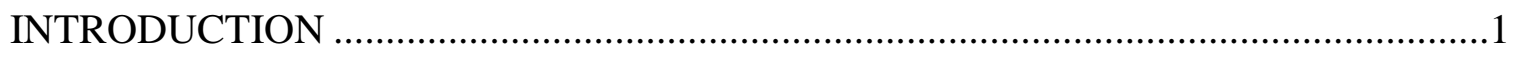

CHAPTER ONE: UNDERSTANDING CORRUPTION IN LATIN AMERICA..............5

Historical Factors and Current Political Characteristics: A Survey of Corruption in

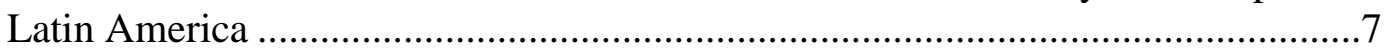

Institutional and Cultural Implications when Examining Corruption...................15

CHAPTER TWO: A CASE FOR EXPERIENCE AND PERCEPTION,

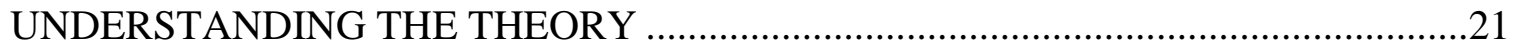

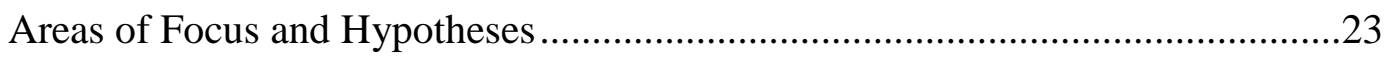

CHAPTER THREE: METHODOLOGY AND DATA ANALYSIS ............................27

The Issue with Perception and Aggregate Indices ..........................................27

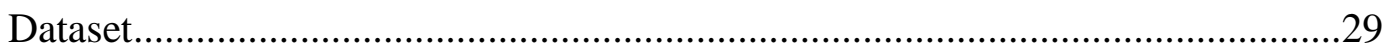

Mediation Models and Robustness Checks .......................................................33

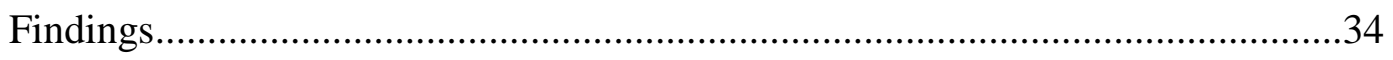

CHAPTER FOUR: CONCLUDING THOUGHTS ...............................................42 


\section{REFERENCES}

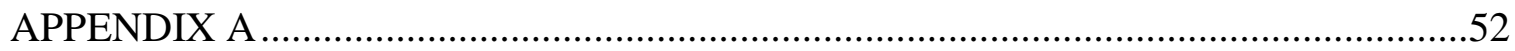

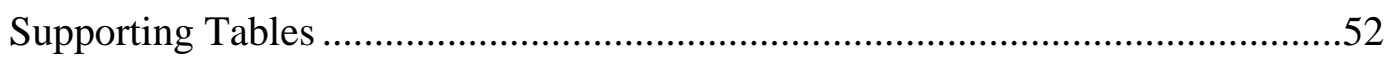




\section{LIST OF TABLES}

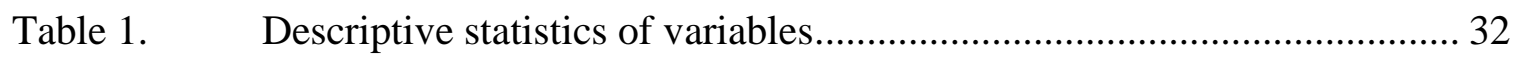

Table 2. Impact of experience and perception of corruption on satisfaction with democracy, using GBRIBE variable to gauge experience with corruption

Table 3. Impact of experience and perception of corruption on satisfaction with democracy, using PBRIBE variable to gauge experience with corruption38

Table A-1. Impact of variables on satisfaction with democracy using linear regression 53

Table A-2. Impact of variables on perception of corruption using linear regression.. 54 


\section{LIST OF FIGURES}

Figure 1. Average Corruption Perception Index Scores by Regions ........................ 6

Figure 2. Percentage of Population Victim of Corruption in 2014 ........................ 7

Figure 3. Visual Representation of the Mediation Model ................................... 25

Figure 4 First mediation model depicting the impact of perception and experience with corruption by government official on satisfaction with democracy . 37

Figure 5. Second mediation model depicting the impact of perception and experience with corruption by police on satisfaction with democracy.... 39 


\section{LIST OF ABBREVIATIONS}

LAPOP

USAID

PRI

CPI
Latin American Public Opinion Project

United States Agency for International Development

Institutional Revolutionary Party

Corruption Perception Index 


\section{INTRODUCTION}

In 2016, the former minister of public works in Argentina was arrested while trying to toss what was described as "an obscene amount of cash" over the walls of a convent in Buenos Aires. The official claimed he stole the money to help, while carrying a military-style assault rifle (Miroff, 2016). While not as colorful or obvious, instances of corruption such as this occur daily in many nations, including Latin America. Corruption is an ailment that many nations experience. It can take different forms and it can negatively affect a country. Its constant presence in the media can derail legitimate business and taint the belief on politicians and public officials.

While some states manage to overcome it, others suffer the consequences of its presence. Regardless of the situation or the type, nations may experience corruption in one form or another. It may occur primarily at local governments, be present when conducting business, or it be a well-known secret across a nation. The ramifications can be comprehensive and handicap progress, affecting economic development, political efficacy, and social stability. Several scholars highlight corruption as a primary cause for underdevelopment (Alam, 1989; Macrae, 1982; O’Higgins, 2006; Theobald, 1999) while others point to corruption as the leading reason for stagnant economies (GyimahBrempong \& Munoz de Gyimah-Brempong, 2006; Sandbrook, 1986; Warren, 2004). I argue that corruption, whether experienced or perceived, impacts the population's satisfaction with democracy and its values, eroding trust in government and formal political structures. In this study, I will implement a mediation model to assess the impact 
of corruption, both experienced and perceived, on individual's attitudes towards democracy in Latin America. This method will measure the impact of those factors separately and jointly.

The presence of corruption alone can derail many initiatives or programs; it can also directly influence perception. One of the most challenging issues when interpreting corruption is the manner in which it is measured and defined. For the purpose of this study, I will rely on the definition implemented by Leite and Weidmann (2001) and Kaufmann, Kraay, and Mastruzzi (2006); corruption is the use of governmental authority for private gain, taking into consideration the use of political favors and campaign contributions (Weyland, 1998). Corruption may have a more pervasive influence at the individual level. Whether corruption is present, the sheer perception of its presence can sway behavior and can impact day to day operations in a country. For this study, I will rely on survey data from the Latin American Public Opinion Project to conceptualize responses regarding corruption and democracy from 22 countries. Focusing the examination in this region provides several benefits. First, there is a shared history and culture between these nations. These characteristics allow for the isolation of cultural factors to a certain extent.

Latin America has a history of dealing with corruption. The continent suffers through several kinds of corruption and the continent's population considers it to be one of the most significant issues affecting their society (Miller \& Chevalier, 2016). Over $77 \%$ of respondents believed anti-corruption laws were ineffective in a survey across Latin America (Miller \& Chevalier, 2016). The following research seeks to analyze this issue, concentrating its efforts on the region. Additionally, countries throughout the 
continent have had a fickle relationship with democracy. For most of its history, there have been several instances of military dictatorships, quasi-democratic efforts, and democratic leaders leaving office enveloped in scandal. Satisfaction in democratic values is an important measure, particularly in young democratic states or those that might be underperforming. A decrease in satisfaction with democracy can lead to less than favorable actions by the population, including an increase in support for more authoritative initiatives, a decrease in participation in national, regional, or local elections, and/or general distrust in the government.

With the previous discussion in place, the following analysis will focus on three areas using a mediation model:

1) The manner in which experience with corruption affects attitudes towards democracy.

2) The way public opinion/perception changes due to experiences with corruption. This particular part of the assessment will showcase an individual's tolerance towards corruption and how potential personal ties affect their overall view on the matter.

3) How experience with corruption's effect on attitudes towards democracy is mediated by a change in perceptions of corruption.

This study offers a series of innovative approaches when dealing with corruption. First, it does not rely on aggregate indices of corruption (such as the Corruption Perception Index, the World Competitiveness Report, or the World Country Risk Guide). This is not rare, as other studies rely on survey data, including the works by Seligson (2002, 2006) among others, but it deviates from the norm. However, distinguishing 
between experiences with corruption and an individual's perception of it is a novel method. It contributes an additional justification on why citizens may show signs of dissatisfaction with democracy. Using a mediation model to account for these relationships further showcases a unique tactic to assess changes in satisfaction with democracy at the individual level.

The study has four subsequent sections. The first section will examine the literature on the subject, identifying a variety of factors that may affect an individual's attitude towards democracy, including gender, religion, and culture. The second portion will delve into the theoretical framework of the analysis, distinguishing between perception and experience with corruption and how it reflects on democratic values. The third segment will cover the methodological analysis of the study, evaluating the virtues of the mediation models and the characteristics of the dataset. Lastly, the fourth section will conclude the article, identifying potential avenues for future research and delineating the impact of the study. 


\section{CHAPTER ONE: UNDERSTANDING CORRUPTION IN LATIN AMERICA}

Latin America currently suffers from high levels of corruption, but there are two ways to observe it. Figure 1 showcases the average score of various world regions based on the Corruption Perception Index (CPI) by Transparency International (2016). Transparency International ranks nations every year. A higher score signifies a better grasp on corruption, better institutional efforts to combat it, and lower levels of corruption. Although the scores from Latin America are not the worst, they lag behind those from Western Europe, Asia Pacific, and the United States and Canada in its continent. Additionally, there is a wide range of scores within Latin America as well. Uruguay leads the charge with a score of 71 while Venezuela, in its current state of turmoil, trails with a score of 17 (Transparency International, 2017). The innate characteristics of each nation will affect the manner in which citizens experience, perceive, and react to corruption. 


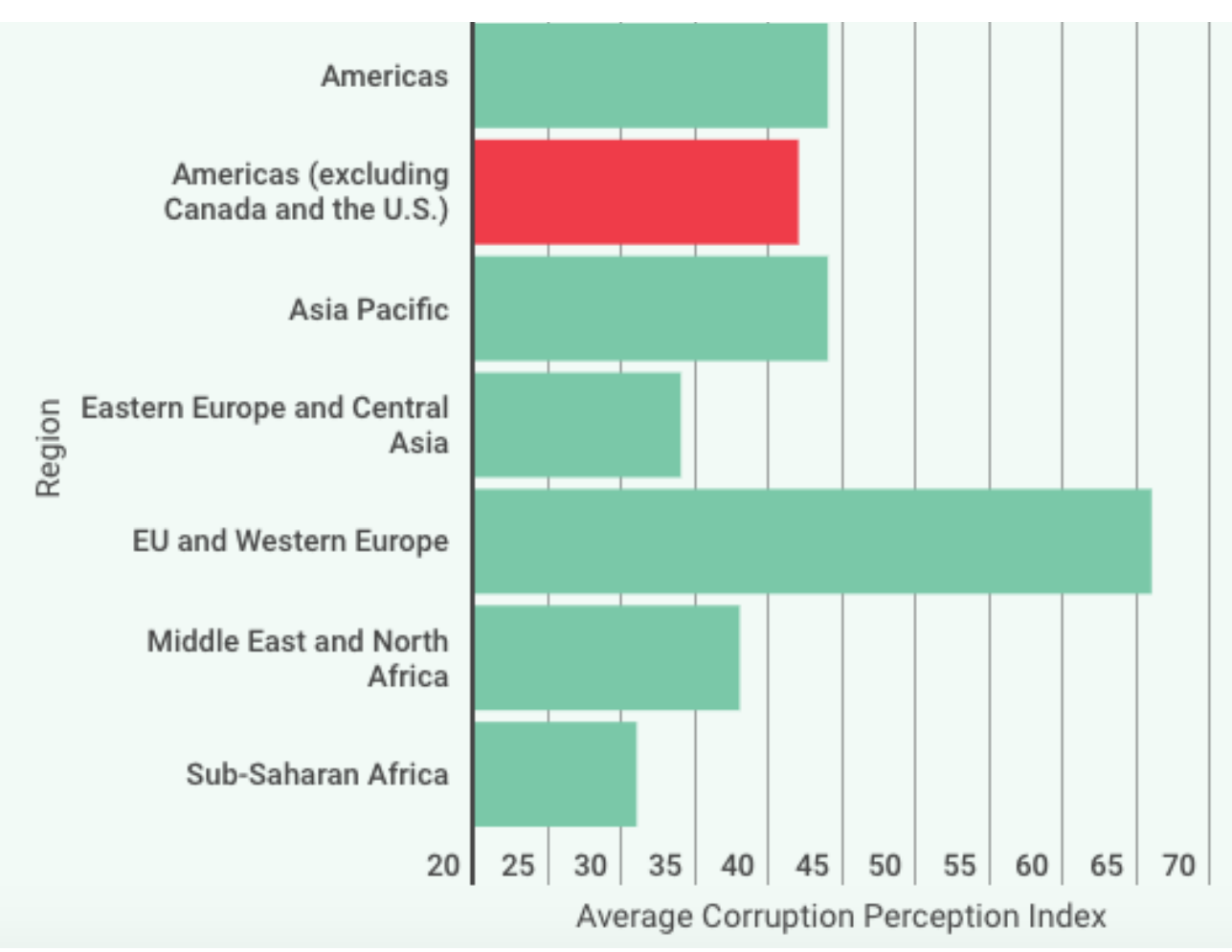

Figure 1. Average Corruption Perception Index Scores by Regions

While, at times, corruption can be hidden in Latin America, it is a common occurrence and it is out in the open. Thomson (2016), using data from Transparency International and USAID, highlights how a significant sector of the population in Latin America experiences corruption first hand. Figure 2 shows the percentage of the population that are victims of corruption. Across the continent, citizens suffered the effects of corruption directly; however, just as the overall scores of the Corruption Perception Index show, there is a wide range of variance between nations. Each country experiences various levels of success when combatting corruption. Chile and Uruguay tend to be the success stories, showcasing how Latin societies may be able to combat the ailment. But other examples, such as Bolivia and Venezuela, continually receive some of the worst scores in the world. Regional economic powerhouses, such as Mexico and 
Brazil, each with their own characteristics and flair, additionally struggle with corruption. The variety of cases delineates the need to observe continental trends, but also take into consideration the national characteristic of each country to better understand this variance.

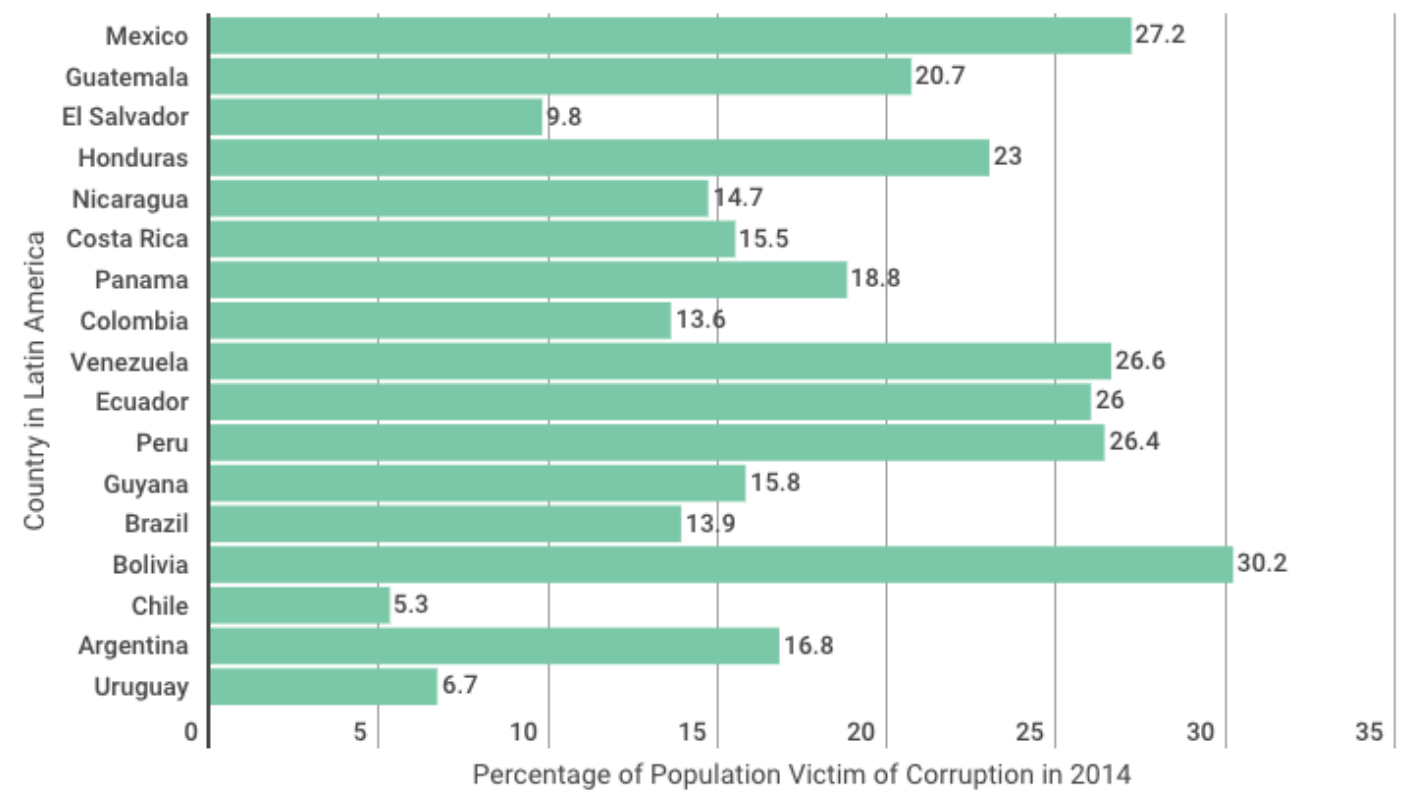

Figure 2. Percentage of Population Victim of Corruption in 2014

\section{Historical Factors and Current Political Characteristics: A Survey of Corruption in \\ Latin America}

One of the most prominent theories regarding corruption is that democracy deters it. Nevertheless, the Latin American case exemplifies that this relationship may not be automatic. Although all nations in the continent have democratic principles, the presence of corruption and mismanagement has reached critical levels in some countries. So, then the question becomes why has democracy been ineffective in reducing corruption in Latin America? There is a similar relationship with economic factors. Several scholars 
point to the free market effectiveness in reducing corruption. Nonetheless, neoliberal measures have not been able to make an impact around this area. Furthermore, Latin America continually experiences boom and bust cycles. The largest economies in the region, Brazil and Mexico, do not fare better in regard to equality and corruption than other nations in the continent. State intervention in the economy makes corruption possible. There are larger number of officials involved in day-to-day processes. This leads to opportunity for said officials to use their influence and expertise to abuse power (Weyland, 1998). However, in Latin America, the opposite is also true. Argentina and Brazil experienced an increase in corruption during the dismantling of state interventions during the Menem and Collor governments (Weyland, 1998). There was no accountability through these processes. Efforts to privatize (and later re-nationalize) industries led to the exploitation of influence and the delivery of political favors for the benefit of select groups in society. Deterring the implementation of safeguards and institutional controls aids political parties and officials in promoting self-serving behavior among their cadre.

While the current political climate aids in understanding the status of many nations, historical characteristics further elucidate them. Several nations in Latin America underwent a military dictatorship period in the 20th century (Needler, 1966; Smith, 2012). After several decades under military rule and, at times, violent repression, states in Latin America started to implement democracies, beginning the third wave of democracy in the world. However, the development of political institutions pose a variety of challenges. Yashar (1999) identifies mixed results by these institutions, failing to establish fully democratic practices. Additionally, the presence of marginalized groups, 
particularly indigenous ones, fragmented societies and affected the political process. O’Donnell (1998) further introduces flaws within the rule of law in Latin America. These shortcomings not only affect society in general terms, but also prevent the establishing of lasting democratic values.

Countries in Latin America share several historical characteristics, the colonial period being one of them. However, the rise of military dictatorships in the middle of the 20th century continues to have an impact in politics, institutions, and social organizations. The radical experiences in governance across the region are present in society today. The military regimes of the late $20^{\text {th }}$ century continue to have a legacy in political institutions. Latin American societies embraced military interventions during periods of democratic misbehavior, particularly during scandals, economic downturns, or rampant acts of corruption. Although rarer presently, military forces carried out over 250 coups d'état in Latin America, many supported by the population (Vanden and Prevost, 2009). These involvements shaped current political institutions, including the bureaucracy. O'Donnell (1979) coins the term bureaucratic authoritarianism to characterize military rule in Latin America and the aftermath of such involvement.

There were many challenges during the rebirth of democracy in the continent. A new generation of leaders focused in addressing the needs of the middle and lower classes. This occurred as a response to poor economic prospects and a disdain of the elite classes in each nation. Additionally, through the use of media, including radio and television, these leaders addressed large sectors of the population that had rarely garnered any support (Weyland, 1998). Through these strategies, political leaders successfully won elections, particularly those for executive leadership positions (Conniff, 2012) and 
political parties stayed in power for long periods of time. A classic example is the Institutional Revolutionary Party (PRI) in Mexico, holding power for 71 years uninterrupted.

Colazingari and Rose-Ackerman (1998) establish a framework in which the implementation of democracy after an authoritative period initiated the development of political institutions that fostered corruption. The authors' primary focus is Italy, making connections with the current environment in Latin America. In Italy and Latin America, the state adopts paternalistic practices, sheltering public and private firms. A classic example of this occurred in the 1990s, as states sought to nationalize several industries. This behavior, in combination with a strong executive branch and an ineffective separation of powers, leads to a situation that promotes corruption. Elected officials have unchecked political power, enabling them to create stable coalitions to suit their needs. In other words, political leaderships established systems that lack accountability, promoting the presence of corruption. Additionally, the authors identify stable coalitions, unchecked political power, and populism as supplementary symptoms of corruption in Latin America. Italy began reshaping public opinion and changing political institutions by establishing independent judicial investigators (the "Clean Hands" initiative). The successes of the strategy could easily be transplanted to Latin America according to the authors. However, their framework continues to value historical events and actions that result in stable institutions that favor the status quo. In other words, corruption is a symptom, or the result, of the formal democratic practices in place. The long-term presence of corruption can have additional ramifications in society and the political process. 
The previous historical characteristics aided in the development of the institutions currently present in Latin America. It shaped the type of leaders the continent elected at more democratic times. One of the reasons corruption is prevalent in Latin America is due to the characteristics of the national government and its leaders. Smulovitz and Peruzzotti (2000) recognize some of these shortcomings by Latin American democracies, focusing on the unconstrained behavior of executive leaders and weaknesses within the judicial branches to restrict such behavior.

While the executive offices welcome unbridled power, the characteristics of the leaders themselves play a role as well. In the early 1990's, a series of leaders across the continent directly appealed to the population. By connecting with disenfranchised groups or citizens that lost faith in political institutions and parties, candidates and leaders made promises to directly solve a variety of ailments and shortcomings from eras past (Agüero and Stark, 2002). This type of politics gave birth to populist candidates, for example Fernando de Collor Mello in Brazil, Carlos Menem in Argentina, and Alberto Fujimori in Peru.

Although extremely prevalent in the continent, populism leads to corruption in two ways. First, popular and charismatic individuals have access to a system that, thanks to their magnetism, does not provide much oversight. They can organize sectors of the population that might feel excluded (Weyland, 2001). Second, populist leaders tend to work with specific groups of supporters and provide them with certain advantages. In most cases, it is very expensive to maintain the base of supporters happy. Therefore, leaders institute a system of exploitation or spoils to obtain the funds and favors necessary to maintain their political career. This type of corruption tends to give a lot of 
power to leaders and their cronies as they attempt to maintain the status quo. Placing allies in additional political offices is a common strategy. As the number of officials in a position to abuse power increases, so does corruption.

Corruption is prevalent in the continent regardless of stronger democratic practices. Higher election costs lead to more blatant cronyism efforts. Candidates and public officials attempt to amass larger election funds to continue their platform and career. Although a large portion of the electorate considers corruption a prominent issue, opposition parties are unable to establish successful platforms to remedy current conditions (Davis, Camp, and Coleman, 2004). Opposition parties are unable to mobilize voters to change the system. This may stem from a closed political system controlling a single party, such as in Mexico, an ineffective leadership structure, or an inability to reach multiple electoral regions to have an impact. High levels of perception of corruption lead voters to remove themselves from the electoral process altogether, setting aside any support for rival parties (Davis et al., 2004). Opposition parties may, at times, be able to exploit corruption levels to achieve political victories. But those circumstances are rare and rely on a combination of other factors. It is more likely for the political system to be de-legitimized than see a sudden change in voters' actions. If this phenomenon continues long-term, democracies will weaken and political participation will decrease. Due to the political structure of most Latin American countries, democratic institutions are failing at discouraging corruption practices.

Davis, Camp, and Coleman (2004) argue that more significant ideological differences between political parties will lead the opposition party to believe the incumbent one is corrupt. To assess their claim, the authors use survey data from three 
nations (Chile, Mexico, and Costa Rica), asking participants what they believe is the biggest issue in the country, whether elections are clean or fraudulent, and the percentage of the government that is corrupt. They note that political affiliation, cultural tendencies towards the political process, and views about the economy are significant indicators of perception. Among their findings, they note that perceived corruption is not a determining factor for voting for the opposition party. However, it can lead voters to withdraw completely from the political process. Additionally, corruption can lead to a decrease in the legitimacy of democracy, eroding trust in public officials and the formal system (Seligson, 2002, 2006). Nevertheless, societies will react to such occurrence differently. León, Araña, and León (2012) found that citizens from various nations have different thresholds about tolerable practices. In their specific scenario, Chilean citizens have a higher standard regarding practices than those from Spain.

Economic factors, such as development, growth, and unemployment, can affect democracies' abilities to combat corruption as well. The wellbeing of the population determines their approval for elected officials and, in turn, their acceptance of democratic delegation. Higher human capital, appropriate levels of inflation and unemployment can lead to strengthening democratic values (Doucouliagos and Ulubaşoğlu, 2008) and give administrations the capacity to sustain prosperous times and attempt to remedy society's ailments. Additionally, there is a correlation between income per capita and democracy because there are features present in a state that will determine both factors (Robinson, 2006). The lack of these qualities may pose a threat on how individuals view democracies due to the lack of perceived benefits they may currently receive from democratic institutions. This might be particularly true in Latin America; a region that has 
experienced non-sustained levels of growth and, as previously mentioned, a history that favors authoritative governments.

Corruption further muddles the issue due to its complex impact on social issues and the local economy. Pedauga, Pedauga, and Delgado-Márquez (2016) introduce conflicting studies; those that observe corruption as a tool for growth and income equality and those that showcase a more nefarious effect. Focusing on Latin America, the authors assert that an increase in corruption has a negative impact on income equality, polarizing sectors of society. This division expands to the political realm, affecting the manner in which political parties and candidates interact with the public. Additionally, in nations with a large informal sector, measures to decrease corruption will also lead to an increase in inequality (Dobson and Ramlogan-Dobson, 2010). This is due to higher costs to conduct business and the discouraging of informal practices. However, those efforts continue to divide society and intensify the disparity between sectors of the population, potentially leading to some of the risks mentioned above.

Leite and Weidmann (1999) find that strong institutions and monitoring efforts can counter some of the negative effects of corruption. In particular, these institutions will have a much more significant impact in developing nations as they benefit from the resurgence of natural resources. However, establishing such measures is not a simple task. Many of them evolve through several iterations based on historical factors (Acemoglu and Robinson, 2012). Efforts to transplant institutions to establish behavioral guidelines fail due to cultural and social frameworks. Leite and Weidmann (1999) additionally conclude that rapid growth prompts an increase in corruption. Developing nations struggle to take advantage of growth when it occurs and institutional control does 
not deter the practice. Then, although growth has the potential to strengthen democratic ties, lack of institutions can lead to corruption and a negative attitude towards democracy due to persistent inequality.

\section{Institutional and Cultural Implications when Examining Corruption}

Latin America has a complicated relationship with democracy. Experiencing or perceiving corruption can alter the manner in which individuals appreciate democracy. A convoluted history and the cultural values of the continent further pose intricacies that affect how the populace respects democratic values and institutions. Additionally, there is a discrepancy between nations, providing a variety of experiences that shape the strength and the future survival of current democratic practices.

When attempting to identify factors affecting democracy, or recognizing characteristics for growth and democratic stability, there are many lines of inquiries presented in the literature. This variety of explanatory variables makes it difficult to identify exclusive plans of actions or explanations that correspond to the experience of a continent. Nevertheless, they elucidate potential factors that play a role in understanding Latin America's relationship with corruption and its failure to combat it. Acemoglu and Robinson (2012) established an economic and historical approach to explain current performance, recognizing the impact colonial history may have on a nation. This particularly applies to Latin America due to their colonial past under the control of Portugal and Spain. Their argument proposes a difference in cultural upbringing based on the colonial power that impacted current values and performance. In other words, Spain and Portugal developed institutions aimed at extracting resources, not developing longterm strategies for governance. These did not amalgamate with democratic governments 
later in time. Fukuyama (1996, 2006), Harrison (1995), Huntington (2011), and Putnam (1993) indicated a cultural framework shaped on traditions and behaviors that influence governance and institutions. Fukuyama $(1992,1996)$ celebrates the almost universal implementation of liberal democracy, recognizing individual characteristics in each nation that prevent the complete implementation of liberty and equality principles. Harrison (1995) applies an anthropological approach showcasing cleavages in society extenuated by ethnic influences and inclinations. Huntington (2011) explained conflict and differences in performance based on cultural features, categorizing areas of the world and assigning Latin America its own category due to variance to other regions. Putnam (1993) identified cultural features and their impact on political institutions and democracy. Helmke and Levitsky (2008) examined political institutions in Latin America, acknowledging that quality matters and informal frameworks affect their performance. Przeworski (2009) sought to understand the connection between democracy and development, identifying a cyclical framework closely related to economic performance and distinguishing the success of democracies over more authoritarian forms of government.

There is an effort to develop and institute a system of interest representation in Latin America, replacing the established system of clientelism (Gay, 2012). But communities continue to use clientelistic practices to this day because they work for them. They are able to rely on this method to receive services and to guarantee political representation and attention. In turn, politicians use clientelism as a way to extend their political careers and foster continued support. This is one of the many ways in which political action intertwines with cultural implications. 
Corruption in Latin America is not unique. However, many of the cultural values present in the continent may promote corrupt practices. Some cultures may have certain pressures to succeed, creating a 'means to an end schema' (Lenz and Lipset, 2000). Due to the lack of opportunity and resultant stress, individuals rely on illegal practices. Some cultures value supporting their families above all else, justifying their participation in illegal practices. In these instances, most individuals would not consider their actions wrong per se. Religious generalizations may come into play as well. Protestant sects tend to be more individualistic, while Catholic sects revolve around the family and the community. Therefore, people make different decisions based on those values. Under Catholic dogma, repentance provides absolution, providing a different mentality towards sin. Many of these characteristics are present in Latin America. The Catholic Church continues to influence the region, establishing strong connections in the communities and within families. One of the primary accounts in the field is the notion that Catholic values foster corruption. Religious stances may promote clientelism and place family and personal relationships above everything else, including the law (Lenz and Lipset, 2000). To many, the population in Latin America supports leaders that can accomplish their agenda and show an image of strength and action. Therefore, at times, the means that leaders use to implement measures are not as important as the results. In other words, parts of the population are willing to disregard the method as long as a project progresses. Religious affiliation additionally provides the means for individuals to organize and share ideas. Lenz and Lipset (2000) connect religion to potential justifications of behavior. The authors recognize two types of corruption related to cultural values: the means-ends schema and amoral feminism. The first characterizes the rationale individuals use to 
justify their actions. Corruption is a tool that is needed in order to advance and meet accomplishments. The second relies on the ties and obligations individuals have to their friends and families, promoting action on behalf of their networks. The two explanations proposed by Lipset and Lenz do not necessarily explain the presence of corruption, but how individuals navigate an environment in which the practice is needed in order to succeed. However, these cultural norms impact the manner in which citizens rationalize and accept behavior, influencing perception.

The preceding cultural characteristics also showcase how corruption may not be exclusively negative. To many, in particular at the micro level, the use of bribes is common, potentially expected. There are a variety of benefits to the population to promote these practices. Whether through bribes or the use of unofficial channels, corruption can overcome deficiencies in the bureaucracy. It may be able to cut red tape and expedite projects (Nye, 1967). To many regions or localities, corruption is an alternate method to gain access to resources, particularly those that may be scarce (Vanden and Prevost, 2009). In other words, it creates opportunity. Whether it is the ability to develop infrastructure, use services, or have the ability to interact with public officials, corruption practices can give individuals and groups and opportunity to accomplish their goals, regardless of what those may be. While some may use this access for personal gain, others seek to benefit the community at-large.

Corruption creates a parallel market and methods to gain access to the political and social systems. This may mean access for underrepresented or discriminated groups to promote their goals (Nye, 1967). Additionally, it may be an avenue for entrepreneurs to promote their ventures. That is to say that through the use of bribes or other practices 
related to corruption, individuals are able to introduce new capital that would not be present under different conditions. Such practices may lead to jobs in the community, better entry to products or services, and the development of the local economy.

Nevertheless, the sheer presence of these alternate systems delegitimizes democratic institutions and members of the government and the bureaucracy. Citizens that rely on methods based on corruption circumvent official steps. Therefore, there is no need to fix a faulty system and democratic institutions do not need to evolve to satisfy the demands of the population.

The previous section aided in elucidating the prevalence and type of corruption currently present in Latin America. It demonstrated a particular relationship between citizens and democracy. Furthermore, it highlighted the tendency in research to implement at-large factors in a society to understand corruption and the type of impacts it may have in a state, including deficits in democracy. Nevertheless, while corruption can have concrete effects on the performance of a state, it may also affect citizens' psyche. Personal traits and connections with specific sectors of the population shape bonds and ideas. In particular, gender, age, and political views may significantly impact behavior and perception. Through these, networks and tendencies develop, affecting political viewpoints.

The following section will begin exploring the repercussions of corruption on democracy. However, instead of utilizing a country-wide approach, I focus on the role of individuals and the manner in which they perceive and experience corruption and how their awareness impacts their satisfaction with democratic practices. Citizens do not experience corruption at a societal level. It is a personal trait. Therefore, I forego most 
national and aggregate indicators that may not fully observe the manner in which corruption (whether experienced or perceived) affects how individual view democracy. I rely on the personal characteristics mentioned above to identify a variety of components that may impact their beliefs. 


\section{CHAPTER TWO: A CASE FOR EXPERIENCE AND PERCEPTION,} UNDERSTANDING THE THEORY

As the previous section elucidated, corruption is a complex topic that can have short and long lasting effects on nations. Generally, the consequences of corruption tend to revolve around economic and political factors. But we must also seek to understand the personal factors and the manner in which corruption affects public opinion ${ }^{1}$. A citizen's day-to-day life and experience will shape their sentiments on several issues, including democracy. Although corruption may be rampant across the continent, not every citizen experiences corruption personally. Bailey and Paras (2006) conducted a survey in Mexico where fewer than $25 \%$ of respondents encountered corruption first-hand. Nevertheless, most respondents identified corruption as concerning. There is a discrepancy between experience with corruption and a citizen's perception of it. Higher awareness leads to lower satisfactions scores with democracy and lower levels of trust with official institutions (Bailey and Paras, 2006). However, Canache and Allison (2008) identify the primary problem. Citizens in Latin America are aware of the high levels of corruption in their respective countries. Additionally, they judge authorities and political institutions based on their awareness about corruption. This connection between perception of corruption and citizens' views on government offices can lead to negative levels of support for democratic practices. Conroy-Krutz and Kerr (2015), in a study in Uganda,

\footnotetext{
${ }^{1}$ I am exclusively looking at micro-levels that impact satisfaction with democracy.
} 
found when satisfaction with the performance of institutions decreases, so does support for democracy. This effect may be more drastic when a citizen's political party is not in power. Anderson and Guillory (1997) found similar findings in Europe, denoting the impact on satisfaction when being part of the political minority.

There is a variety of explanations for distinct levels of support for democracy, ranging from the micro/individual level to societal/national ones. As previously mentioned, being part of the political majority affects such support. However, the type of democracy also affects these results. Political minorities in systems that are more consensual tend to be more supportive of democracy as well (Anderson and Guillory, 1997). But there are additional large scale factors that may impact it. For example, Wagener, Schneider, and Halla (2009) find that high-quality institutions, particularly those that limit corruption or promote the rule of law, increases an individual's satisfaction with democracy. Additionally, economic factors have a role as well. Economic performance indicators, in particular those that relate to citizen's wellbeing, such as unemployment, growth, and inflation tend to be related with satisfaction levels (Wagener et al., 2009).

As previously stated, this study will primarily focus on micro-level factors that affect a citizen's level of satisfaction with democracy. Several studies followed this approach. Catterberg (1990) finds that individuals in lower socio-economic groups tend to have less favorable views on democracy. These directly relate to the findings by Wagener, Schneider, and Halla (2009) and overall performance by a state. Frey and Stutzer (2002) connect personal and financial wellbeing to overall happiness levels that can impact overall satisfaction levels. Furthermore, Graham and Pettinato (2001), in a 
study in Latin America, recognized a mutual relationship. Pro-democracy and pro-market attitudes increase happiness levels. In turn, content citizens are more likely to support democratic institutions and have pro-market approaches. Moreover, innate characteristics of citizens may play a factor on how they rationalize or observe democratic institutions. In a study based in the European Union, Karp, Banducci, and Bowler (2003) found that individuals with higher education levels, had a based understanding of politics, and would discuss politics often tended to be more satisfied with democracy. Demographic characteristics may play a role depending on the situation. Anderson and Guillory (1997) observed some instances of significance, but their results varied depending on the country. On the other hand, Karp et al. (2003) recognized age and gender as significant factors in their study.

\section{Areas of Focus and Hypotheses}

Perception is an area that does not receive much attention. However, due to the pervasive nature of corruption and its effects at multiple levels of society, perception can have an impact in the ways citizens respond and behave. The following study will seek to test and understand the role of corruption on satisfaction with democracy from two different angles. First, it will examine the impact of experiencing corruption first-hand has on satisfaction with democracy. Second, it will assess whether perceiving high levels of corruption has similar effects.

Experience with corruption showcases the cracks in the system. These are instances in which a government official requested a bribe in order to provide support or an advantage to an individual. Undergoing such occurrence first hand can have a devastating effect on an individual and how it observes its government. These occasions 
break trust between government officials and the population. It is not wrong to assume that an individual might generalize their experience and suppose a widespread environment in which corruption and bribery are prominent. These emotions could result in a negative attitude towards the government, institutions, and democracy itself.

Democracy's primary strength, the willingness by the public to delegate power, is also its biggest weakness since it relies on public opinion and satisfaction. Democracy relies on the citizens' beliefs in order to gain legitimacy (Agüero and Stark, 2002). Whether those beliefs are accurate or not, they carry significant weight and importance. Perception of the current state of affairs plays a role in the manner in which citizens develop their beliefs.

While direct experience with corruption might exemplify the environment in a country, perception is fickler. Citizens will set their mindset and expectations about their government. The Latin America Public Opinion Project found that, on average, citizens believe that corruption is common or very common in their countries, even when not experiencing it first-hand. In this instance, individuals are basing their assumption on the information they receive from the media and their social circle. Considering the sheer number of public scandals involving public officials over the last few decades, it is not a surprise individuals feel that way. Haggard and Kaufman (1995) additionally identified a large sector of the population in Latin America felt dissatisfied with democracy. In some instances, over $60 \%$ of the population did not have favorable views on democratic institutions. Philip (2003) cites surveys in which $11 \%$ of Chilean citizens admit to supporting authoritarian rule under specific circumstances. 
Although it is prominent, studies rarely examine the impact of perception. In this instance, I will assess the role of it and its link to satisfaction with democracy. It is appropriate to assume that experience with corruption and perceptions of it are linked and share some similarities. Individuals that experienced corruption should have a higher perception of it. At the same time, experience is not the most appropriate lens to base perceptions. An individual may encounter corruption directly, but it may be an isolated case that will end up tainting someone's perception. Additionally, the opposite is also true. Large-N studies may not identify characteristics at the individual level. In turn, anecdotal studies fail to recognize the biased perspectives of citizens that have been negatively impacted by corruption. In order to analyze the effect, I propose to use a mediation model to determine the bearing each component has individually and jointly. A minority of the population of this study experienced corruption. But, by including them in the analysis, I am able to account for the reservations expressed above. Additionally, the models will include personal characteristics, such as age, gender, education levels, and political ideologies to determine the impact of these characteristics on perception. Figure 3 below is a graphic representation of the mediation model, identifying the relation between components.

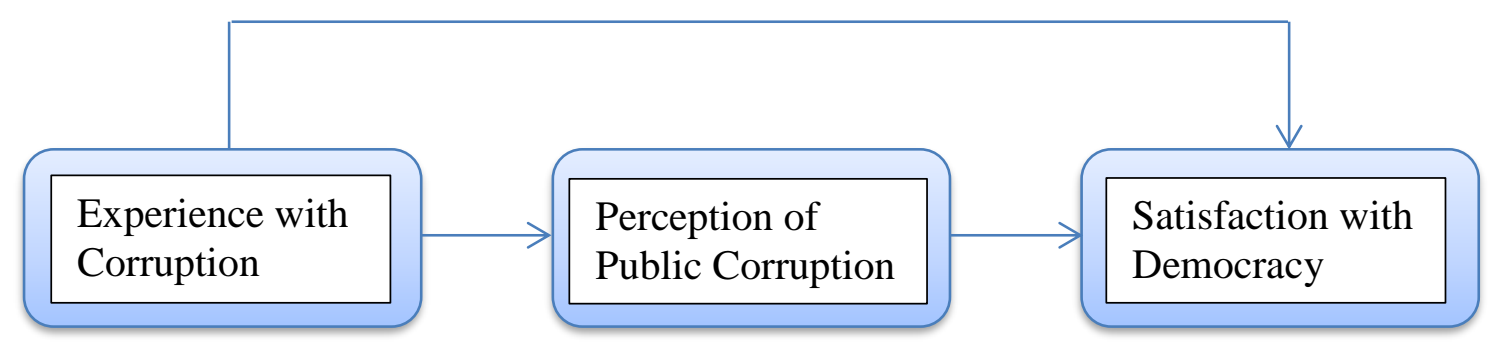

Figure 3. Visual Representation of the Mediation Model 
The research will revolve around the following three hypotheses:

- Hypothesis \#1: Experience with corruption lowers an individual's satisfaction with democracy.

- Hypothesis \#2: A high perception of corruption lowers an individual's satisfaction with democracy.

- Hypothesis \#3: Experience with corruption increases an individual's perception of corruption. 


\section{CHAPTER THREE: METHODOLOGY AND DATA ANALYSIS}

The following section will focus on the methodological section of the study. The first section will justify the use of the results of the Latin American Public Opinion Project (LAPOP), identifying benefits over aggregate indices. The second will delineate the characteristics of the dataset of the research, introducing the values of the variables and details of the LAPOP survey. The third section will explain the methodology directly, commenting on the use of the mediation models and additional regressions for robustness. The final section will provide an assessment of the results.

\section{The Issue with Perception and Aggregate Indices}

The measurement of corruption is complicated. The field at-large primarily relies on the use of indices, particularly those from Transparency International, the World Country Risk Guide, and the World Bank. This has become common practice.

Additionally, there is a high level of correlation among indices, so authors have the flexibility to use them almost interchangeably (Ahmad, 2001). Nevertheless, there are a series of concerns that, depending on the line of questioning, indices may not be the most appropriate measure.

Corruption perception indices are aggregate calculations. The nature of the data makes it so not all its sources will have similar definitions or understanding of corruption, potentially affecting the results (Andersson and Heywood, 2009). Actual corruption experience does not necessarily align with reported corruption perception (Donchev and Ujhelyi, 2009). Indices may not be able to differentiate such characteristics. Additionally, 
Andersson and Heywood (2009) recognize three problems with indices. First, most indices will measure perception rather than concrete measures. At times, indices will alternate depending on the type of data they implement or the surveys they use. Such management of data may not provide adequate consistency to contrast results and trends. Second, since most indices rely on surveys, the results depend on how individuals interpret the questions and their attitude towards corruption. Depending on the social situation of a state, the answers may not align with the national experience. Lastly, and related to the previous point, the variance in answers from one year to the next establish an index in which the meaning of the score from year to year is meaningless. In turn, the results may also pose a challenge when comparing outcomes across nations. Larger countries suffer penalties and scores do not showcase the intricacies between states, in particular those suffering from high levels of corruption (Donchev and Ujhelyi, 2009). This study measures encounters with corruption at the individual level. A citizen does not directly experience corruption at a societal one. Aggregate measures miss this nuance and do not allow to test how perception and experience operate jointly.

To overcome some of the shortcomings of aggregated indices, this study will rely on survey data from the Latin American Public Opinion Project. There are several benefits to highlight:

1. Standardization of results: individuals respond to the survey every two years. Although researchers at times introduce minor updates, the questionnaire remains similar to compare results across time.

2. The survey distinguishes between actual experiences with corruption and perception. This characteristic allows for the development of a mediation 
model by separating the two measures. Additionally, since the survey identifies perception and experience differently, the answers should reflect the variance.

3. The survey also includes questions regarding the attitudes of respondents towards democracy.

4. Although comparing results across countries may lead to potential problems resembling those from the indices, intra-national assessments are possible.

The survey is not perfect and continues to have cross-national shortcomings. However, the presence of all components for the study and a clear distinction between perception and experience of corruption aids in limiting factors that may compromise the results of the study.

\section{Dataset}

For this study, I will use the results of the Latin American Public Opinion Project (LAPOP) survey. The study will use surveys from 2006, 2008, 2010, 2012, and 2014, gathering data from 22 different countries. ${ }^{2}$ By focusing on Latin America, the study isolates specific cultural characteristics. Although each nation has its own history and characteristics, the similarity between countries allows to bypass cultural features that may be difficult to exemplify and measure. Additionally, the shared past between nations may help restrict foreign influences and other historical influences. The questionnaires evolve and many nations add specific questions applicable to their population.

\footnotetext{
2 The countries include Mexico, Guatemala, El Salvador, Honduras, Nicaragua, Costa Rica, Panama, Colombia, Ecuador, Bolivia, Peru, Paraguay, Chile, Uruguay, Brazil, Venezuela, Argentina, Dominican Republic, Haiti, Jamaica, Guyana, and Belize.
} 
Nonetheless, the base survey remains fairly similar in each iteration. It is worth noting that there were instances of nations not asking specific questions in some years of the survey. For some nations, the number of observations is decidedly smaller. Nevertheless, they provide sufficient data points for the analysis.

As previously mentioned, the dependent variable (DEMOC) will measure satisfaction with democracy. The survey codes this variable using a 4-point Likert scale, ranging from very dissatisfied (1) to very satisfied (4). In order to measure experience with corruption I use two separate questions. The first one asks respondents whether a government official asked them for a bribe (GBRIBE). The second one asks whether a police officer asked them for one (PBRIBE). Both variables are binary, giving respondents the option to answer yes or no. Although similar in characteristic and fairly correlated with each other, using different questions to measure experience with corruption helps with the robustness of the study. Bribes are a good measure of corruption. They are one of several types of corruption, identifying an instance in which a public official abused their power for personal gain. They recognize specific instances in which a citizen was directly affected by them. Additionally, it is an occurrence in which the act occurs at the micro level, aligning with the values of the study. Depending on the iteration of the model, I use these variables separately or jointly to assess their impact. The mediator variable relies on an additional question about the respondents' perception of corruption among public officials (PERC). Again, the survey codes the answers in a 4point Likert scale, having values ranging from very uncommon (1) to very common (4). I use five control variables in all the models. The GENDER variable, as the name implies, recognizes the gender of the respondent. A value of 0 identifies the respondent as 
female and a value of 1 the respondent as male. I expect women to be more satisfied with democracy, reflecting previous quantitative approaches (Anderson and Guillory, 1997; Wagner, Dufour, and Schneider, 2003; Wagner, Schneider, and Halla, 2009; Lühiste, 2013). Women play an integral role in Latin America in the development of social capital and the creation of networks for the delivery of services (Molyneux, 2002). However, I would also expect them to experience the negative effects of corruption more often and have a higher perception of it due to their status in society. AGE, again self-explanatory, determines the age of the individual in years. This variable is complex when setting expectations. On the one hand, older people tend to be less satisfied with democracy. In regards to corruption, this makes sense as older generations endured corruption longer. On the other, however, these generations experienced some of the horrors of military dictatorships that may lead to support of democratic values. Nevertheless, I would expect that older individuals have higher democratic satisfaction levels (Anderson and Guillory, 1997; Wagner et al., 2003; Wagner et al., 2009; Lühiste, 2013). IDEOL determines the political ideology of the respondents using a 10-point scale. The values for this variable range from 1 (liberal) to 10 (conservative). I presume individuals with a lower score will have a higher satisfaction level with democracy (Lühiste, 2013). URBAN is a binary variable that determines whether the respondent lives in an urban or rural area. A value of 0 exemplifies rural residence and a value of 1 signifies urban residence. I expect the urban population to have higher levels of satisfactions with democracy. Lastly, EDU measures the number of years of official schooling an individual received. If an individual had 18 or more years of schooling it was coded as 18 . I expect a higher level 
of education to lead to higher levels of satisfaction with democracy (Anderson and Guillory, 1997; Wagner et al., 2003; Wagner et al., 2009; Lühiste, 2013).

Table 1 below details the characteristics of the variables included in the study.

There are three points worth noting. First, experience with police corruption is more prevalent. Second, the sample of respondents demonstrates an even distribution in several categories, including gender, political ideology, and education. The sample tends to be more urban. Nevertheless, that is to be expected due to residential trends. Lastly, although all variables have over 110,000 responses, most models will have a sample of around 70,000. This is due to respondents not answering specific questions. Therefore, I excluded those cases.

\section{Table 1. Descriptive statistics of variables}

\begin{tabular}{|c|c|c|c|c|c|}
\hline Variable & $\begin{array}{r}\text { Number of } \\
\text { Observations }\end{array}$ & $\begin{array}{r}\text { Mean } \\
\text { Values }\end{array}$ & $\begin{array}{l}\text { Standard } \\
\text { Deviation }\end{array}$ & $\begin{array}{r}\text { Minimum } \\
\text { Values }\end{array}$ & $\begin{array}{r}\text { Maximum } \\
\text { Values }\end{array}$ \\
\hline $\begin{array}{l}\text { Satisfaction with } \\
\text { Democracy } \\
\text { (DEMOC) }\end{array}$ & 73,067 & 2.54 & 0.72 & 1 & 4 \\
\hline $\begin{array}{l}\text { Experienced bribe } \\
\text { by government } \\
\text { official (GBRIBE) }\end{array}$ & 75,124 & 0.06 & 0.25 & 0 & 1 \\
\hline $\begin{array}{l}\text { Experienced bribe } \\
\text { by police officer } \\
\text { (PBRIBE) }\end{array}$ & 75,124 & 0.11 & 0.32 & 0 & 1 \\
\hline $\begin{array}{l}\text { Perception of } \\
\text { Corruption (PERC) }\end{array}$ & 75,524 & 3.17 & 0.86 & 1 & 4 \\
\hline GENDER & 75,524 & 0.52 & 0.50 & 0 & 1 \\
\hline AGE & 75,524 & 38.67 & 15.49 & 16 & 101 \\
\hline $\begin{array}{l}\text { Political Ideology } \\
\text { (IDEOL) }\end{array}$ & 75,524 & 5.56 & 2.62 & 1 & 10 \\
\hline $\begin{array}{l}\text { Urban or rural } \\
\text { region (URBAN) }\end{array}$ & 75,524 & 0.67 & 0.47 & 0 & 1 \\
\hline $\begin{array}{l}\text { Education level in } \\
\text { years (EDU) }\end{array}$ & 75,524 & 9.38 & 4.36 & 0 & 18 \\
\hline
\end{tabular}




\section{Mediation Models and Robustness Checks}

The study relies on the use of a mediation model. The mediation model allows us to examine the dependent variable (satisfaction with democracy), while taking into consideration the primary independent variable (experience with corruption) and the mediator variable (perception of corruption). In other words, instead of simply analyzing the direct causal relationship between dependent and independent variables, the mediation model recognizes the influence the independent variable has on the mediator variable and how these two impact the dependent variable individually and jointly. This method proves convenient when the independent variable has a significant effect on the mediator variable; the independent variable has a significant effect on the dependent variable in the absence of a mediator variable; the mediator variable has a significant effect on the dependent variable; and the effect of the independent variable on the dependent variable decreases in the presence of the mediator variable (Preacher, 2018). A mediation model is another type of regression analysis. It does not imply causality. But it conducts three multiple regression analyses simultaneously (independent variable $\rightarrow$ dependent variable, independent variable $\rightarrow$ mediator variable, mediator variable $\rightarrow$ dependent variable) following the previous parameters (Kenny, 2018). This study includes all the previous characteristics, justifying the methodological model.

For this study, I will rely on the Sobel-Goodman mediation test (Sobel, 1982; Baron and Kenny, 1986). This approach provides the tools needed to examine all the observations in the dataset. It is worth explaining two specific decisions as well. Although more complex, but potentially more rigorous, the Tingley method (Imai, Keele, and Tingley, 2010) was not an option in this circumstance. Due to the sheer number of 
observations and the need to implement a matrix, computers cannot process the simulation. Additionally, I use country level fixed effects to account for variation in survey responses at the individual level that is influenced by country-level factors.

\section{Findings}

In order to measure the impact of variables in regard to democracy I conducted standard OLS regressions, including one of the independent variables (police officer asking for a bribe or government official asking for one), the control variables, and country-level fixed effects, developing standard OLS coefficients. The results for these regressions are in Table A-1 in the appendix. All variables showed significance at the 0.05 confidence level, apart from the urban/rural measure. Experience with corruption, whether from a government employee or a police officer, will lead to a less auspicious view on democracy. Education has a negative relationship with satisfaction with democracy while political ideology, gender, and age have a negative one. In other words, more education leads to unfavorable (potentially more critical) views of democracy while more conservative political views and older individuals tend to have a more positive perception of it. Additionally, men tend to offer more support for democratic values.

However, when introducing country fixed effects, the results change slightly.

First, the variable measuring urban/rural characteristic is significant. It has a negative relationship regardless of which measure I use to determine if a respondent experienced corruption. Additionally, age loses significance when using police bribery as the primary independent variable. The significance and direction of all other variables resemble those from the previous iteration. 
With some guidelines in place as a result of the previous regressions, I performed additional linear regressions to determine the effect of the independent and control variables on perception of corruption. The results for these regressions are in table A-2 in the appendix. In these instances, all the variables showed statistical significance. Experience with corruption, whether from government officials or police, has a negative effect on perception of corruption. As expected, individuals are more likely to believe corruption is more prevalent if they experienced it first-hand. Age, gender, education, and urban/rural characteristics also have a positive relationship. On the other hand, political ideology has a positive relationship.

While the previous regressions establish a relationship among variables, in order to determine their joint and individual effects I conducted a mediation analysis of them. The results showcased a statistical significance among variables in the mediation models. Experience with corruption directly affects perception of corruption and satisfaction with democracy. Independently, perception of corruption also affects satisfaction. Table 2 provides a complete overview of the first mediation model. It uses occurrences in which government officials asked for a bribe in order to gauge experience with corruption. As expected, experience with corruption lowers satisfaction with democracy by 0.10 units. However, when taking into consideration the mediator variable, that impact is a decrease of 0.096 units. In other words, perception accounts for almost $10 \%$ of the impact experience with corruption has on democracy. Additionally, experience with corruption increases perception by 0.15 units. The most interesting finding aligns with one of the hypothesis of the study. Perception of corruption decreases satisfaction with democracy. 
A one unit increase in perception results in a 0.06 decrease of support for democracy. In the mediation model, all variables are significant at the 0.01 level.

Table 2. Impact of experience and perception of corruption on satisfaction with democracy, using GBRIBE variable to gauge experience with corruption

\begin{tabular}{|c|c|c|c|}
\hline & $\begin{array}{r}\text { Satisfaction } \\
\text { with Democracy }\end{array}$ & $\begin{array}{r}\text { Perception of } \\
\text { Corruption }\end{array}$ & $\begin{array}{r}\text { Mediated } \\
\text { Satisfaction with } \\
\text { Democracy }\end{array}$ \\
\hline GBRIBE & $\begin{array}{r}-0.106 * * \\
(0.010)\end{array}$ & $\begin{array}{r}0.155^{* *} \\
(0.013)\end{array}$ & $\begin{array}{r}-0.096 * * \\
(0.010)\end{array}$ \\
\hline PERC & & & $\begin{array}{r}-0.068 * * \\
(0.003)\end{array}$ \\
\hline GENDER & $\begin{array}{r}0.016 * * \\
(0.005)\end{array}$ & $\begin{array}{r}0.040 * * \\
(0.006)\end{array}$ & $\begin{array}{r}0.019 * * \\
(0.005)\end{array}$ \\
\hline AGE & $\begin{array}{r}0.000 \\
(0.000)\end{array}$ & $\begin{array}{r}0.003 * * \\
(0.000)\end{array}$ & $\begin{array}{r}0.001 * * \\
(0.000)\end{array}$ \\
\hline IDEOL & $\begin{array}{r}0.011 * * \\
(0.001)\end{array}$ & $\begin{array}{r}-0.004 * * \\
(0.001)\end{array}$ & $\begin{array}{r}0.011 * * \\
(0.001)\end{array}$ \\
\hline URBAN & $\begin{array}{r}-0.049 * * \\
(0.006)\end{array}$ & $\begin{array}{r}0.056^{* *} \\
(0.007)\end{array}$ & $\begin{array}{r}-0.045^{* *} \\
(0.006)\end{array}$ \\
\hline EDU & $\begin{array}{r}-0.006 * * \\
(0.001)\end{array}$ & $\begin{array}{r}0.019 * * \\
(0.001)\end{array}$ & $\begin{array}{r}-0.005^{* *} * \\
(0.001)\end{array}$ \\
\hline $\mathrm{N}$ & 75,379 & 75,379 & 75,379 \\
\hline $\mathrm{R}^{2}$ & 0.061 & 0.051 & 0.067 \\
\hline \multicolumn{2}{|c|}{ Sobel Z-Value } & & -10.82 \\
\hline \multicolumn{2}{|c|}{ Proportion of total effect that is mediated } & & 0.100 \\
\hline \multicolumn{4}{|c|}{$\begin{array}{l}\text { Table entries represent the coefficient for the variables with the standard errors in } \\
\text { parenthesis. Country level fixed effects are included, but omitted from the table for } \\
\text { readability. }\end{array}$} \\
\hline
\end{tabular}

Figure 4 below visually displays the statistical relationship among variables for the first mediation model, using a government official asking for a bribe as the measure for corruption. The mediation model aids in establishing that roughly 10 percent of the experience with corruption effect on satisfaction with democracy is explained by 
perception of corruption. In other words, while encountering corruption impacts satisfaction with democracy and perception, perception of public corruption has an independent effect on satisfaction as well.

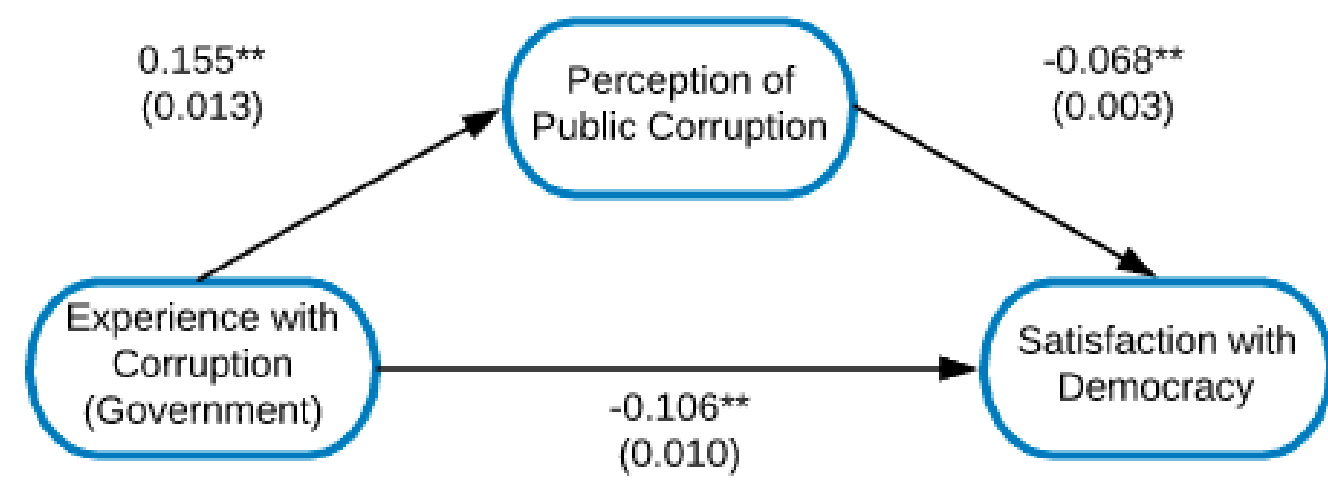

Sobel Coefficient: -0.011 (0.001)

Proportion of total effect mediated: 0.100

$$
* \mathrm{p}<0.05 * * \mathrm{p}<0.01
$$

Figure 1 First mediation model depicting the impact of perception and experience with corruption by government official on satisfaction with democracy

The second mediation model mirrors the first one; except that it utilizes instances of corruption by police officers as the independent variable. The results are very similar when using police corruption as the variable. Table 3 summarizes the outcomes for all the variables. Gender, age, and political ideology have positive coefficients. In turn, the urban measure and the education variable have negative ones. 
Table 3. Impact of experience and perception of corruption on satisfaction with democracy, using PBRIBE variable to gauge experience with corruption

\begin{tabular}{|c|c|c|c|}
\hline & $\begin{array}{r}\text { Satisfaction } \\
\text { with Democracy }\end{array}$ & $\begin{array}{r}\text { Perception of } \\
\text { Corruption }\end{array}$ & $\begin{array}{r}\text { Mediated } \\
\text { Satisfaction with } \\
\text { Democracy } \\
\end{array}$ \\
\hline PBRIBE & $\begin{array}{r}-0.082 * * \\
(0.008)\end{array}$ & $\begin{array}{r}0.108 * * \\
(0.010)\end{array}$ & $\begin{array}{r}-0.075^{* * *} \\
(0.008)\end{array}$ \\
\hline \multicolumn{3}{|l|}{ PERC } & $\begin{array}{r}-0.069^{* * *} \\
(0.003)\end{array}$ \\
\hline GENDER & $\begin{array}{r}0.019 * * \\
(0.005)\end{array}$ & $\begin{array}{r}0.037^{* *} \\
(0.006)\end{array}$ & $\begin{array}{r}0.022^{* *} \\
(0.005)\end{array}$ \\
\hline AGE & $\begin{array}{r}0.000 \\
(0.000)\end{array}$ & $\begin{array}{r}0.003^{* *} \\
(0.000)\end{array}$ & $\begin{array}{r}0.000^{* * *} \\
(0.000)\end{array}$ \\
\hline IDEOL & $\begin{array}{r}0.011 * * \\
(0.001)\end{array}$ & $\begin{array}{r}-0.004 * * \\
(0.001)\end{array}$ & $\begin{array}{r}0.011^{* *} \\
(0.001)\end{array}$ \\
\hline URBAN & $\begin{array}{r}-0.051 * * \\
(0.006)\end{array}$ & $\begin{array}{r}0.056^{* *} \\
(0.007)\end{array}$ & $\begin{array}{r}-0.047 * * * \\
(0.006)\end{array}$ \\
\hline EDU & $\begin{array}{r}-0.006^{* *} \\
(0.001)\end{array}$ & $\begin{array}{r}0.019^{* *} \\
(0.001)\end{array}$ & $\begin{array}{r}-0.005^{* * *} \\
(0.001)\end{array}$ \\
\hline $\mathrm{N}$ & 75,524 & 75,524 & 75,524 \\
\hline $\mathrm{R}^{2}$ & 0.061 & 0.051 & 0.067 \\
\hline \multicolumn{2}{|c|}{ Sobel Z-Value } & & -9.83 \\
\hline \multicolumn{2}{|c|}{ Proportion of total effect that is mediated } & & 0.090 \\
\hline
\end{tabular}

Figure 5 visually showcases the results of the mediation model. Experience with police corruption decreases satisfaction by 0.08 units, a smaller effect than corruption by government officials. In similar fashion to the previous model, when taking into consideration the mediator variable, the impact decreases to 0.075 units. Again, perception has an impact on the overall outcome of experience, accounting for $9 \%$ of the effect. In turn, experience with corruption also increases perception of it by 0.11 units. Lastly, as the previous model showcased, a one unit increase in perception of corruption 
leads to a decrease in satisfaction by 0.07 units. The results of the second mediation model resemble those of the first. It establishes that about 9 percent of the effect of experience with corruption on satisfaction with democracy is explained by the individual's perception of corruption.

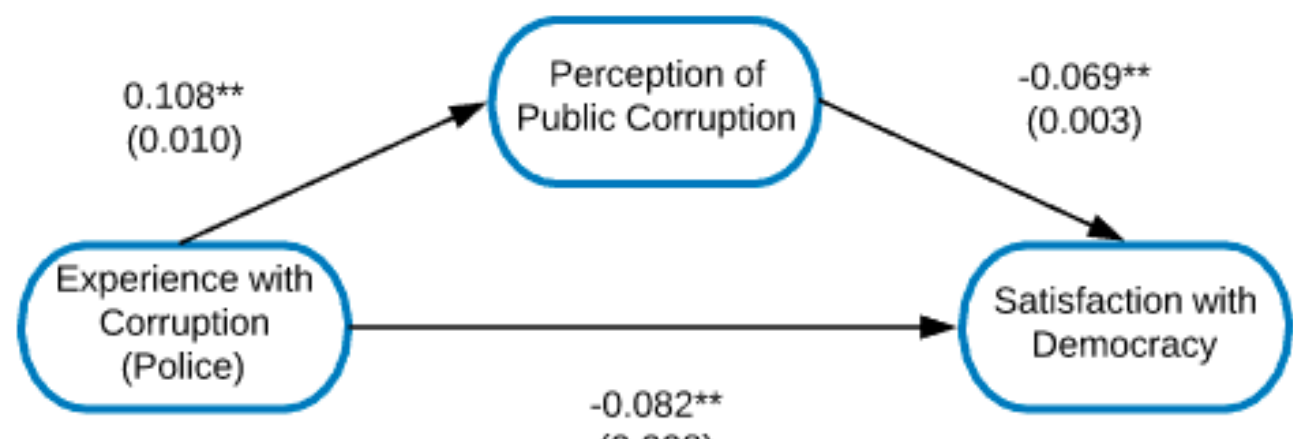

$(0.008)$

Sobel Coefficient: -0.007

$(0.001)$

Proportion of total effect mediated: 0.090

$$
* \mathrm{p}<0.05 * * \mathrm{p}<0.01
$$

Figure 5. Second mediation model depicting the impact of perception and experience with corruption by police on satisfaction with democracy

The variable to determine the type of corruption experienced does not affect the results. Experience with corruption has a negative relationship with satisfaction with democracy and a positive relationship with perception of corruption. These relationships are significant at the 0.01 level. The control variables acted accordingly to the previous regression models. They are all significant at the 0.01 level.

The mediation models contributed evidence supporting all three hypotheses of the study. Christensen and Lægreid (2003) find that a citizen's trust in a political institution extends to others. The opposite seems to be true as well. Experiencing corruption first 
hand lowers satisfaction with democracy. As other studies show, individuals link experiences with corruption, in this particular case a governmental official or a police officer asking for a bribe, to other political institutions or organizations, lowering satisfaction with democracy. There is a direct link between coming into contact with corruption and the level of satisfaction an individual may have with democracy.

The mediation model also helps clarify that experiencing corruption tends to affect an individual's perception of the whole system. In other words, a citizen's experience will shape their overall view of democracy. However, a small sector of the population experiences corruption first hand. In this specific study, $6 \%$ experienced a government official ask for a bribe and $10 \%$ experienced a police officer asking for one. Nevertheless, awareness of corruption tends to be at a high level across the population as demonstrated in the LAPOP survey.

Awareness to the level of corruption has a distinct and separate effect on satisfaction with democracy, supporting the second hypothesis of the study. Having a high level of awareness of corruption, regardless of actual experience, impacts democratic beliefs. In a continent where most citizens consider corruption a primary issue in society, this finding poses concerns to the continued development of democratic institutions and the backing it may receive from the population.

The control variables performed as expected. There are certain qualities, primarily those related to social standing, that affect the manner in which citizens rationalize their support for democracy. Gender, age, education, urban/rural status, and political ideology, are significant at different stages in the models. While national or regional characteristics shape the discussion on how well a democracy is performing, this study showcases that 
there are individual factors that impact support for democracy, potentially creating concerns regarding long-term stability of democratic practices. Direct experience with corruption affects individuals' view on democracy. But perception matters as well. 


\section{CHAPTER FOUR: CONCLUDING THOUGHTS}

Corruption can impact a nation at many different levels. Worrisomely, corruption may influence the constancy of democratic governments and the population's belief in democratic practices. Furthermore, as the region struggles to contain corruption, a question arises: will the electorate resort to more authoritative governments in an effort to reign in corruption and provide stability? This study identified the effects of corruption on an individual's satisfaction with democracy. Additionally, perception of corruption is a contributing factor that operates jointly and independently from experience with corruption. In a continent such as Latin America, the long-term repercussions are uncertain. As many nations do not seem to have an appropriate plan to combat corruption, what will be the status of these countries moving forward? How will this affect the manner in which elected officials react? Regardless of the answer to these questions, corruption affects several areas of society. Nevertheless, its pervasive impact on democracy may be its most significant issue affecting the prosperity of developing countries.

This study is the first step in expanding the knowledge of how corruption perception, whether justified or not, leads to mistrust in democracy. It provides an introduction to the role of corruption in a society and the various factors people use to rationalize their perception regarding this issue. The use of a survey and statistical models elucidate the variety of factors that can impact this trait. As nations continue to develop and implement various efforts to overcome underdevelopment and other social perils, this 
study points that there might not be a clear solution or initiative that may remedy the way individuals identify corruption.

The models confirmed that there are personal, cultural and social characteristics that shape the population's mindset and their perspective on democracy. Additionally, experience with corruption has a different effect on satisfaction with democracy than the perception of it. Both variables affect satisfaction with democracy negatively. While encounters with corruption affects awareness, perception has an independent effect on satisfaction. The models provide support for a variety of variables influencing satisfaction with democracy. Using a large-N approach further clarifies social mentalities across nations. Additionally, by focusing on a specific region of the world, cultural factors should not influence the results.

Moving forward, there are a series of adjustments possible. First, although the dataset is robust, I would like to expand the number of observations to include additional years of the survey. As responses become more standard in the survey, it will provide additional levels of significance and consistency. Second, I would like focus on the factors that affect perception. While research in the past focused on corruption in general terms, understanding the psychological nature of an individual's perception on bribery will further solidify efforts to combat it. In particular, the results of the study do not support assumptions that perception of corruption impacts satisfaction with democracy. Lastly, this study provides awareness for national characteristics that may alleviate or aggravate factors in regards to corruption or the perception of it. While large $\mathrm{N}$ studies provide us an opportunity to observe the big picture, following attempts must start looking at individual nations to recognize native factors influencing the system. 
Corruption is a complex issue. But as the field continues to examine the causes and effects of it, more subtle characteristics will come to light. Previous studies highlight corruption as the primary factor affecting economic and social wellbeing. However, as this study recognizes, it may also impact the stability of democratic practices. Nations or organizations seeking to remedy the situation must examine the problem as a whole. It is not only important to combat actual corruption levels, but populations must be confident that officials are working on their behalf in order to decrease perception levels as well. 


\section{REFERENCES}

Acemoglu, D., \& Robinson, J. A. (2012). Why nations fail: the origins of power, prosperity, and poverty. New York: Crown Business.

Agüero, F., \& Stark, J. (Eds.). (2002). Fault lines of democracy in post-transition Latin America. Miami, FL: North-South Center Press.

Ahmad, N. (2001). Corruption Perception Indices: A Comparative Analysis. The Pakistan Development Review,40(4), 813-830. Retrieved November 26, 2017.

Alam, M. S. (1989). Anatomy of Corruption: An Approach to the Political Economy of Underdevelopment. SSRN Electronic Journal, 48(4), 441-456. Retrieved January 13, 2018.

Anderson, C. J., \& Guillory, C. A. (1997). Political Institutions and Satisfaction with Democracy: A Cross-National Analysis of Consensus and Majoritarian Systems. American Political Science Review, 91(01), 66-81. Retrieved February 24, 2018.

Andersson, S., \& Heywood, P. M. (2009). The Politics of Perception: Use and Abuse of Transparency Internationals Approach to Measuring Corruption. Political Studies, 57(4), 746-767.

Bailey, J., \& Paras, P. (2006). Perceptions and Attitudes about Corruption and Democracy in Mexico. Mexican Studies/Estudios Mexicanos, 22(1), 57-82. Retrieved February 24, 2018.

Baron, R. M., \& Kenny, D. A. (1986). The moderator-mediator variable distinction in social psychological research: Conceptual, strategic, and statistical considerations. Journal of Personality and Social Psychology, 51(6), 1173-1182. 
Canache, D., \& Allison, M. E. (2008). Perceptions of Political Corruption in Latin American Democracies. Latin American Politics and Society,47(3), 91-111. Retrieved November 14, 2017.

Catterberg, E. (1990). Attitudes Towards Democracy in Argentina During the Transition Period. International Journal of Public Opinion Research, 2(2), 155-168. Retrieved February 24, 2018.

Christensen, T., \& Lægreid, P. (2003, April). Trust in Government - the Significance of Attitudes Towards Democracy, the Public Sector and Public Sector Reforms [Scholarly project]. In Stein Rokkan Centre for Social Studies Bergen University Research Foundation. Retrieved February 19, 2018.

Colazingari, S., \& Rose-Ackerman, S. (1998). Corruption in a Paternalistic Democracy: Lessons from Italy for Latin America. Political Science Quarterly, 113(3), 447470. Retrieved August 15, 2017.

Conniff, M. L. (2012). Populism in Latin America. Tuscaloosa, Ala.: University Alabama Press.

Conroy-Krutz, J., \& Kerr, N. (2015). Dynamics of Democratic Satisfaction in Transitional Settings: Evidence from a Panel Study in Uganda. Political Research Quarterly, 68(3), 593-606. Retrieved February 24, 2018.

Davis, C. L., Camp, R. A., \& Coleman, K. M. (2004). The Influence of Party Systems on Citizens' Perceptions of Corruption and Electoral Response in Latin America. Comparative Political Studies, 37(6), 677-703. Retrieved September 18, 2017.

Dobson, S., \& Ramlogan-Dobson, C. (2010). Is there a trade-off between inequality and corruption? Evidence from Latin America. Economics Letters, 107(2), 102-104

Donchev, D. D., \& Ujhelyi, G. (2009). What Do Corruption Indices Measure? SSRN Electronic Journal. 
Doucouliagos, H., \& Ulubaşoğlu, M. A. (2008). Democracy and Economic Growth: A Meta-Analysis. American Journal of Political Science, 52(1), 61-83. Retrieved February 22, 2018.

Frey, B. S., \& Stutzer, A. (2002). What Can Economists Learn from Happiness Research? Journal of Economic Literature, XL, 402-435. Retrieved March 6, 2018.

Fukuyama, F. (1992). The end of history and the last man. New York: Free Press.

Fukuyama, F. (1996). Trust: the social virtues and the creation of prosperity. New York: Free Press Paperbacks.

Gay, R. (2012). Clientelism, Democracy, and Violence in Rio de Janeiro. In Clientelism in Everyday Latin American Politics (1st ed., pp. 81-98). New York: Palgrave Macmillan.

Graham, C., \& Pettinato, S. (2001). Happiness, Markets, and Democracy: Latin America in Comparative Perspective. Journal of Happiness Studies, 2(3), 237-268. Retrieved March 6, 2018.

Gyimah-Brempong, K., \& Munoz de Gyimah-Brempong, S. (2006). Corruption, Growth, and Income Distribution: Are there Regional Differences? Economics of Governance, 7(3), 245-269. Retrieved January 13, 2018.

Haggard, S., \& Kaufman, R. R. (1995). The Political economy of democratic transitions. Princeton, NJ: Princeton University Press.

Harrison, L. E. (1995). Who prospers?: how cultural values shape economic and political success. New York, NY: Basic Books.

Helmke, G., \& Levitsky, S. (2008). Informal Institutions and Democracy Lessons from Latin America. Baltimore: Johns Hopkins University Press.

Huntington, S. P. (2011). The clash of civilizations and the remaking of world order. New York: Simon \& Schuster Paperbacks. 
Imai, K., Keele, L., \& Tingley, D. (2010). A general approach to causal mediation analysis. Psychological Methods,15(4), 309-334. Retrieved December 20, 2017.

Karp, J. A., Banducci, S. A., \& Bowler, S. (2003). To Know it is to Love it? Comparative Political Studies, 36(3), 271-292. Retrieved March 6, 2018.

Kaufmann, D., Kraay, A., \& Mastruzzi, M. (2006, December). Measuring Corruption: Myths and Realities[Scholarly project]. In World Bank. Retrieved August 08, 2017, from http://www1.worldbank.org/publicsector/anticorrupt/corecourse2007/Myths.pdf

Kenny, D. A. (2018, January 26). Mediation. Retrieved March 15, 2018, from http://davidakenny.net/cm/mediate.htm

Leite, C. A., \& Weidmann, J. (1999). Does Mother Nature Corrupt? Natural Resources, Corruption, and Economic Growth. SSRN Electronic Journal. Retrieved August $15,2017$.

León, C. J., Araña, J. E., \& León, J. D. (2012). Correcting for Scale Perception Bias in Measuring Corruption: an Application to Chile and Spain. Social Indicators Research, 114(3), 977-995. Retrieved August 11, 2017.

Lenz, G., \& Lipset, S. (2000). Corruption, culture, and markets. In Culture Matters: How Values Shape Human Progress (pp. 112-125). New York, NY: Basic Books.

Lühiste, K. (2013). Social Protection and Satisfaction with Democracy: A Multi-level Analysis. Political Studies,62(4), 784-803. Retrieved February 18, 2018.

Macrae, J. (1982). Underdevelopment and the economics of corruption: A game theory approach. World Development, 10(8), 677-687. Retrieved January 13, 2018.

Miller \& Chevalier. (2016). 2016 Latin America Corruption Survey (Rep.). Retrieved January 13, 2018, from https://www.millerchevalier.com/sites/default/files/resources/2016-LatinAmerica-Corruption-Survey-Full-Report.pdf

Miroff, N. (2016, June 15). It was for the nuns, said Argentine politician caught with millions in cash outside convent. Retrieved February 01, 2018, from 
https://www.washingtonpost.com/news/worldviews/wp/2016/06/15/it-was-forthe-nuns-said-argentine-politician-caught-with-millions-in-cash-outsideconvent/?utm_term $=.886850690986$

Molyneux, M. (2002). Gender and the Silences of Social Capital: Lessons from Latin America. Development and Change, 33(2), 167-188. Retrieved November 12, 2017.

Needler, M. C. (1966). Political Development and Military Intervention in Latin America. American Political Science Review, 60(03), 616-626. Retrieved January $13,2018$.

Nye, J. S. (1967). Corruption and Political Development: A Cost-Benefit Analysis. American Political Science Review, 61(02), 417-427. Retrieved March 8, 2018.

O’Donnell, G. A. (1979). Modernization and bureaucratic-authoritarianism: studies in South American politics. Berkeley, CA: University of California. Institute of International Studies.

O'Donnell, G. (1998). Polyarchies and the (un)rule of law in Latin America. Madrid: Centro de estudios avanzados en ciencias sociales.

O’Higgins, E. R. (2006). Corruption, Underdevelopment, and Extractive Resource Industries. Business Ethics Quarterly, 16(2), 235-254.

Philip, G. (2003). Democracy in Latin America: Surveying Conflict and Crisis. Cambridge/Oxford: Polity Press.

Pedauga, L. E., Pedauga, L. D., \& Delgado-Márquez, B. L. (2016). Relationships between corruption, political orientation, and income inequality: evidence from Latin America. Applied Economics, 49(17), 1689-1705. Retrieved October 5, 2017.

Preacher, K. J. (2018). Calculation for the Sobel Test. Retrieved March 08, 2018, from http://quantpsy.org/sobel/sobel.htm 
Przeworski, A. (2009). Democracy and development: political institutions and material well-being in the world, 1950-1990. Cambridge: Cambridge University Press.

Putnam Robert. (1993). Making Democracy Work: Civic Traditions in Modern Italy. Princeton: Princeton University Press.

Robinson, J. A. (2006). Economic Development and Democracy. Annual Review of Political Science, 9, 503-527. Retrieved February 23, 2018.

Sandbrook, R. (1986). The state and economic stagnation in Tropical Africa. World Development, 14(3), 319-332. Retrieved January 13, 2018.

Seligson, M. A. (2002). The Impact of Corruption on Regime Legitimacy: A Comparative Study of Four Latin American Countries. The Journal of Politics,64(2), 408-433. Retrieved November 14, 2017.

Seligson, M. A. (2006). The Measurement and Impact of Corruption Victimization: Survey Evidence from Latin America. World Development,34(2), 381-404. Retrieved November 14, 2017.

Smith, P. H. (2012). Democracy in Latin America political change in comparative perspective. New York: Oxford University Press.

Smulovitz, C., \& Peruzzotti, E. (2000). Societal Accountability in Latin America. Journal of Democracy, 11(4), 147-158. Retrieved November 14, 2017.

Sobel, M. E. (1982). Asymptotic Confidence Intervals for Indirect Effects in Structural Equation Models. Sociological Methodology, 13, 290-312. Retrieved December 20, 2017.

Theobald, R. (1999). Corruption, development and underdevelopment. Basingstoke: Macmillan.

Thomson, S. (2016, June 15). Corruption in Latin America is skyrocketing. Here's why that's good news. Retrieved January 13, 2018, from https://www.weforum.org/agenda/2016/06/corruption-in-latin-america

Transparency International. (2017, January). Corruption Perceptions Index 2016 (Rep.). Retrieved January 13, 2018, from 
http://issuu.com/transparencyinternational/docs/2016_cpireport_en?e=2496456/4 $\underline{3483458}$

Vanden, H. E., \& Prevost, G. (2009). Politics of Latin America: the power game. New York, NY: Oxford University Press.

Wagner, A. F., Dufour, M., \& Schneider, F. (2003). Satisfaction Not Guaranteed Institutions and Satisfactions with Democracy in Western Europe (Working Paper Number 910, pp. 1-39, Rep.). CESIFO.

Wagner, A. F., Schneider, F., \& Halla, M. (2009). The quality of institutions and satisfaction with democracy in Western Europe - A panel analysis. European Journal of Political Economy, 25(1), 30-41. Retrieved February 22, 2018.

Warren, M. E. (2004). What Does Corruption Mean in a Democracy? American Journal of Political Science,48(2), 328-343. Retrieved January 13, 2018.

Weyland, K. G. (1998). The Politics of Corruption in Latin America. Journal of Democracy,9(2), 108-121. Retrieved November 14, 2017.

Weyland, K. (2001). Clarifying a Contested Concept: Populism in the Study of Latin American Politics. Comparative Politics, 34(1), 1. Retrieved September 20, 2017.

Yashar, D. J. (1999). Democracy, Indigenous Movements, and Postliberal Challenge in Latin America. World Politics, 52(1), 76-104. 
APPENDIX A

Supporting Tables 
Table A-1. Impact of variables on satisfaction with democracy using linear regression

\begin{tabular}{|c|c|c|c|c|}
\hline & $\begin{array}{r}\text { Corruption by } \\
\text { Government } \\
\text { Officials }\end{array}$ & $\begin{array}{r}\text { Corruption by } \\
\text { Police Officers }\end{array}$ & $\begin{array}{c}\text { Corruption } \\
\text { (using both } \\
\text { measures) }\end{array}$ & $\begin{array}{r}\text { Corruption } \\
\text { (using both } \\
\text { measures) and } \\
\text { Perception }\end{array}$ \\
\hline PERC & & & & $\begin{array}{r}-0.067^{* *} \\
(0.003)\end{array}$ \\
\hline GBRIBE & $\begin{array}{r}-0.105^{* *} \\
(0.010)\end{array}$ & & $\begin{array}{r}-0.075^{* *} \\
(0.012)\end{array}$ & $\begin{array}{r}-0.064^{* *} \\
(0.012)\end{array}$ \\
\hline PBRIBE & & $\begin{array}{r}-0.083 * * \\
(0.008)\end{array}$ & $\begin{array}{r}-0.059^{* *} \\
(0.009)\end{array}$ & $\begin{array}{r}-0.054^{* * *} \\
(0.009)\end{array}$ \\
\hline GENDER & $\begin{array}{r}0.015^{* *} \\
(0.005)\end{array}$ & $\begin{array}{r}0.018^{* * *} \\
(0.005)\end{array}$ & $\begin{array}{r}0.019 * * \\
(0.005)\end{array}$ & $\begin{array}{r}0.018^{* * *} \\
(0.006)\end{array}$ \\
\hline AGE & $\begin{array}{l}0.000^{*} \\
(0.000)\end{array}$ & $\begin{array}{r}0.000 \\
(0.000)\end{array}$ & $\begin{array}{l}0.000 * \\
(0.000)\end{array}$ & $\begin{array}{c}0.000 * \\
(0.000)\end{array}$ \\
\hline IDEOL & $\begin{array}{r}0.011 * * \\
(0.001)\end{array}$ & $\begin{array}{r}0.011 * * \\
(0.001)\end{array}$ & $\begin{array}{r}0.011 * * \\
(0.001)\end{array}$ & $\begin{array}{r}0.014 * * \\
(0.001)\end{array}$ \\
\hline URBAN & $\begin{array}{r}-0.049 * * \\
(0.006)\end{array}$ & $\begin{array}{r}-0.051 * * \\
(0.006)\end{array}$ & $\begin{array}{r}-0.049 * * \\
(0.006)\end{array}$ & $\begin{array}{r}-0.045^{* *} \\
(0.006)\end{array}$ \\
\hline EDU & $\begin{array}{r}-0.006^{* * *} \\
(0.001) \\
\end{array}$ & $\begin{array}{r}-0.006^{* *} \\
(0.001) \\
\end{array}$ & $\begin{array}{r}-0.006^{* * *} \\
(0.001) \\
\end{array}$ & $\begin{array}{r}-0.004^{* *} \\
(0.001) \\
\end{array}$ \\
\hline $\mathrm{N}$ & 77,784 & 77,941 & 77,523 & 77,523 \\
\hline $\mathrm{R}^{2}$ & 0.062 & 0.062 & 0.062 & 0.067 \\
\hline
\end{tabular}

Table entries represent the coefficient for the variables with the standard errors in parenthesis. Country level fixed effects are included, but omitted from the table for readability.

$* \mathrm{p}<0.05, * * \mathrm{p}<0.01$ 
Table A-2. Impact of variables on perception of corruption using linear regression

\begin{tabular}{lrrr}
\hline & $\begin{array}{r}\text { Corruption by } \\
\text { Government Officials }\end{array}$ & $\begin{array}{r}\text { Corruption } \\
\text { by Police Officers }\end{array}$ & $\begin{array}{r}\text { Corruption } \\
\text { (using both measures) }\end{array}$ \\
\hline GBRIBE & $0.161^{* *}$ & & $0.131^{* *}$ \\
& $(0.012)$ & $0.106^{* *}$ & $(0.013)$ \\
PBRIBE & & $(0.009)$ & $0.068^{* *}$ \\
& $0.037^{* *}$ & $0.010)$ \\
GENDER & $0.040^{* *}$ & $(0.006)$ & $(0.006)$ \\
& $(0.006)$ & $0.003^{* *}$ & $0.003^{* *}$ \\
AGE & $0.003^{* *}$ & $(0.000)$ & $(0.000)$ \\
& $(0.000)$ & $-0.005^{* *}$ & $-0.005^{* *}$ \\
IDEOL & $-0.005^{* *}$ & $(0.001)$ & $(0.001)$ \\
& $(0.001)$ & $0.049^{* *}$ & $0.047^{* *}$ \\
URBAN & $0.049^{* *}$ & $(0.007)$ & $(0.007)$ \\
& $(0.007)$ & $0.019^{* *}$ & $0.019^{* *}$ \\
EDU & $0.019^{* *}$ & $(0.001)$ & $(0.001)$ \\
& $(0.001)$ & 86,830 & 86,380 \\
$\mathrm{~N}$ & 86,672 & 0.050 & 0.051 \\
$\mathrm{R}^{2}$ & 0.050 & 0.050 & \\
\hline
\end{tabular}

Table entries represent the coefficient for the variables with the standard errors in parenthesis. Country level fixed effects are included, but omitted from the table for readability.

$* \mathrm{p}<0.05, * * \mathrm{p}<0.01$ 